\title{
Clinical Evaluation of Practolol, a New Cardioselective Beta-blocking Agent in Angina Pectoris
}

\author{
G. SANDLER, ${ }^{*}$ M.D., M.R.C.P. ; G. A. CLAYTON,† M.B., CH.B., M.R.C.P.
}

Summary: In a controlled double-blind study practolol, $\checkmark$ a new cardioselective beta-blocking drug, was given to 15 patients with angina pectoris, and compared with propranolol $80 \mathrm{mg}$. q.d.s. The dose of practolol ranged from 200 to $600 \mathrm{mg}$.b.d. and was decided by initial open titration in individual patients. Though practolol did not influence the incidence of angina or glyceryl trinitrate consumption, it increased the duration of exercise possible in exercise tests and reduced the amount of ischaemic $S \rightarrow T$ depression in the radiocardiogram during exercise. Propranolol reduced the incidence of angina and, in the exercise tests, increased the amount and duration of exercise but did not affect the degree of S-T depression. Unlike propranolol, practolol did not produce any adverse effects on bronchial smooth muscle. Hence it is concluded that practolol is an effective drug in treating angina, and in the dosage used is of potential value in patients with asthmatic bronchitis and angina. It should, however, be used cautiously in anginal patients with heart failure.

\section{Introduction}

The introduction of beta-receptor blocking agents in the treatment of angina pectoris has been an important advance in this difficult therapeutic field. Pronethalol was the first drug of this type to be used successfully in treating angina (Dornhorst and Robinson, 1962), but was soon replaced by propranolol, which was more potent and was also free of the undesirable side-effects of pronethalol (Black et al., 1964). Propranolol itself, however, may lead to adverse effects on myocardial function (Chamberlain, 1966; Stephen, 1966) and also on the bronchial tree (McNeill, 1964). The development of practolol (4-(2-hydroxy-3-isopropylaminopropoxy)-acetanilide; I.C.I. 50172; Eraldin) was therefore of considerable interest, since this drug appears to be a cardioselective betablocking agent with some intrinsic sympathomimetic activity (Barrett et al., 1968) which might have no deleterious effects on myocardial function. A preliminary study of the use of practolol in normal and anginal subjects gave encouraging results (Areskog and Adolfsson, 1969), but the route of administration of the drug was mainly intravenous. It was decided, therefore, to carry out a controlled double-blind evaluation of oral practolol in the treatment of angina, basing the assessment primarily on objective criteria provided by exercise tolerance tests, and at the same time a comparison was made in the same patients between practolol and propranolol, which has already established itself widely in the treatment of angina (Gillam and Prichard, 1965; Hamer and Sowton, 1966; Wolfson et al., 1966).

\section{Patients and Methods}

Sixteen patients with typical attacks of angina pectoris entered the study. There were 11 men and five women aged 33 to 64 years. None was suffering from or had previously developed left or right ventricular failure. Myocardial infarction had occurred in three, but at least one year had elapsed since the episode, and in all the patients studied the angina

*Consultant Physician, St. Helen Hospital, Barnsley. †Medical Registrar, St. Helen Hospital, Barnsley. had settled down to a relatively stable pattern. Glyceryl trinitrate was taken freely for the anginal attacks, the weekly consumption ranging from 1 to 139 tablets. All patients showed $\mathrm{S}-\mathrm{T}$ depression in the electrocardiogram on exercise, ensuring that an objective index of myocardial ischaemia was present for evaluation of drug action. The preparations studied were practolol, propranolol $80 \mathrm{mg}$. q.d.s., and a placebo, a double-blind technique being employed. The dose of propranolol used for comparison was decided on the basis of studies indicating the adequacy of this dose in treating angina (Hamer et al., 1964; Keelan, 1965).

Since very little information was available regarding a potentially effective oral dose of practolol, a pilot study was carried out in six patients to indicate the likely dose range. These six patients were started on $200 \mathrm{mg}$. of practolol twice daily, the dose being increased by $50 \mathrm{mg}$. b.d. at fortnightly intervals until the patient either improved substantially in the frequency of his angina or until he developed adverse sideeffects. Particular attention was paid to the effects of practolol on the blood pressure. It was found that the likely effective dose of practolol was between 250 and 500 mg. b.d. During the pilot study one woman aged 52 had to be withdrawn owing to the development of severe hypotension (98/60 lying and $72 / 50$ standing) following six weeks' treatment with practolol $300 \mathrm{mg}$. b.d. It is of interest that subsequent progressive reduction of the dose to $50 \mathrm{mg}$. b.d. was still accompanied by dizziness and hypotension, so that the drug was finally discontinued.

After this pilot study an additional 10 patients entered the trial, starting on practolol $200 \mathrm{mg}$. b.d. increasing at weekly intervals to the effective dose controlling the angina or until side-effects precluded further increases. When each patient reached the optimal dose of practolol he entered the doubleblind part of the study. Since the half-life of practolol is 12 hours and that of propranolol two hours (Fitzgerald and Scales, 1968) a problem arose regarding the frequency of administration of the two preparations. In order to make the double-blind technique credible the problem was solved by giving identical capsules four times daily, each capsule containing active drug in the case of propranolol, but the middle two doses containing placebo in the case of practolol. In addition, a period of treatment with placebo alone in all four capsules was carried out.

\section{Double-Blind Study}

With the commencement of the double-blind study all patients attended the clinic monthly, and the study began with a control period of one month when the only drug taken for angina was glyceryl trinitrate. During the next three months the patients were given, in random order, individual monthly supplies of identical capsules containing practolol in the daily dose attained in the pilot study, propranolol $80 \mathrm{mg}$. q.d.s., and placebo q.d.s., neither the patient nor the observer knowing which drug had been supplied. In addition, each patient was given a specific number of glyceryl trinitrate tablets at each visit to be used freely for their anginal attacks; they were also given a record card and were asked to fill it in each day, stating only the number of attacks they had had that day. At each monthly visit this card was collected and a new one issued, and the remaining glyceryl trinitrate tablets were counted, giving a more objective assessment of the number of 
attacks. To eliminate any errors from a carry-over effect of the previous month's therapy, only the last two weeks of the four-weel period were used in obtaining the incidence of angina: artacks and the number of glyceryl trinitrate tablets consumed. Any sid:-effects during the previous month were also noted

Exercise tolerance tests were carried out at the beginning of the study and at subsequent monthly visits. The test used was a modification of Master's two-step (Sandler, 1961). In addition to conventional electrocardiography recording chest lead V5 before and after exercise, the patient was monitored continuously during exercise by radiocardiography, which is more sensitive in revealing ischaemic change and also safer by ensuring that ischaemic change can be detected immediately, especially if unaccompanied by angina, allowing the exercise to be terminated immediately (Sandler, 1967). Depression of the S-T segment of plane or sagging contour lasting at least 0.08 second in either the radiocardiogram or V5 was accepted as indicating myocardial ischaemia (Lloyd-Thomas, 1961; Master and Rosenfeld, 1961; Bellet et al., 1962); junctional depression was accepted as significant only when the QX/QT ratio exceeded 50\% (Master and Rosenfeld, 1961). The indices of assessment which were recorded during the exercise test were the number of circuits accomplished by the patient and the exercise time before angina, or ischaemic change, or both, developed in the electrocardiogram; the duration of angina; the degree and duration of $S-T$ depression either in the radiocardiogram or in lead V5; and the heart rate before and during exercise. In addition, the resting blood pressure was measured in the lying and standing positions before each exercise test was begun, to determine whether any of the preparations taken during the previous month had exerted a hypotensive effect. The nature and the purpose of the investigation were made clear to all the patients, and all gave their consent to it.

In addition to exercise electrocardiography each patient had an assessment of respiratory function by means of the Vitalograph, the indices recorded being the forced expiratory volume at one second (F.E.V.1) and the forced mid-expiratory flow (F.M.F.) (middle $50 \%$ of the forced vital capacity) which give a satisfactory indication of the development of bronchospasm (Leuallen and Fowler, 1955). Other screening investigations during the study included haemoglobin, white cell count, platelet count, blood urea, and liver function tests (serum bilirubin, alkaline phosphatase, zinc sulphate turbidity, and alanine aminotransferase).

\section{Results}

In view of the well-known placebo response in antianginal trials (Greiner et al., 1950) the results obtained with practolol and propranolol were assessed by comparison with the placebo period and not with the control period. Table 1 TABLE I.-W'eekly Incidence of Recorded Angina and Weekly Glyceryl
Trinitratc (ionsumption (Mean Values for 15 Patients)

\begin{tabular}{|c|c|c|c|}
\hline & Placebo & Practolol & Propranolol \\
\hline $\begin{array}{l}\text { No. of Recorded attacks: } \\
\text { Mean } \\
\text { S.E... } \\
\text { Mean change }\end{array}$ & $\begin{array}{l}8 \cdot 3 \\
2 \cdot 3\end{array}$ & $\begin{array}{r}9.1 \\
3.0 \\
-0.9 \\
2.0 \\
>0.3\end{array}$ & $\begin{array}{r}5.8 \\
1.6 \\
-2.5^{*} \\
1.4 \\
<0.05\end{array}$ \\
\hline 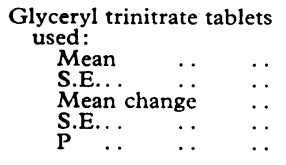 & $\begin{array}{r}25 \cdot 3 \\
9 \cdot 1\end{array}$ & $\begin{array}{c}35.0 \\
11.1 \\
+9.7 \\
10.4 \\
>0.15\end{array}$ & $\begin{array}{c}41.9 \\
12.2 \\
+16.6 \\
10.7 \\
>0.05\end{array}$ \\
\hline
\end{tabular}

S.E. $=$ Standard error. $\quad *$ Significant change $(P<0.05)$. shows the weekly incidence of angina recorded by the patients and the weekly consumption of glyceryl trinitrate during the placebo period and the periods of treatment with the active drugs. In this and subsequent tables assessment of the effects of active medication has been based mainly on a statistical analysis of the differences occurring in individual patients and not on comparison of the mean values for the group as a whole. There was a significant reduction in the weekly incidence of angina recorded by the patients after propranolol but not practolol therapy, but this was not accompanied by a significant reduction in the glyceryl trinitrate consumption. Nor did practolol significantly reduce glyceryl trinitrate consumption.

The results of the exercise tolerance tests are shown in Table II. There was no significant difference in the number

TABLE II.-Exercise Tolerance Tests: Number of Circuits Accomplished and Duration of Exercise (Mean Values for 15 Patients)

\begin{tabular}{|c|c|c|c|c|}
\hline & & Placebo & Practolol & Propranolol \\
\hline 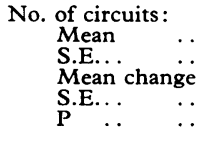 & $\begin{array}{l}\cdots \\
\cdots \\
\cdots \\
\cdots\end{array}$ & $\begin{array}{r}43 \cdot 8 \\
9 \cdot 0\end{array}$ & $\begin{array}{c}55.9 \\
10.1 \\
+12.1 \\
7.3 \\
>0.05\end{array}$ & $\begin{array}{r}52.8 \\
9.9 \\
+9.0 \\
5.3 \\
>0.05\end{array}$ \\
\hline $\begin{array}{cr}\text { Duration } & \text { of } \\
\text { (sec.): } & \\
\text { Mean } & \ldots \\
\text { S.E... } & \ldots \\
\text { Mean change } \\
\text { S.E... } & \ldots \\
\text { P .. } & \ldots\end{array}$ & \begin{tabular}{c|} 
cise \\
$\ldots$ \\
$\cdots$ \\
$\cdots$ \\
$\cdots$ \\
$\ldots$
\end{tabular} & $\begin{array}{r}391 \\
96\end{array}$ & $\begin{array}{l}585 \\
123 \\
+194^{*} \\
107 \\
<0.05\end{array}$ & $\begin{array}{r}544 \\
132 \\
+153 \\
103 \\
>0.05\end{array}$ \\
\hline
\end{tabular}

*Significant change $(\mathrm{P}<0.05)$.

of circuits accomplished with practolol or propranolol compared with the placebo, but practolol did significantly increase the duration of the exercise. Because of the truncated nature of the distribution of these results (the exercise was halted if 100 circuits were accomplished) Wilcoxon's (1945) signed rank test was also used to analyse these data. On this basis practolol again led to a significant increase in the duration of exercise $(\mathbf{P}<0.01)$ but did not alter the number of circuits carried out, while propranolol resulted in significantly more circuits accomplished $(P<0.05)$ and also significantly lengthened the duration of exercise $(\mathrm{P}<0.05)$. Comparison of practolol and propranolol showed no significant difference in the beneficial action of both drugs on the duration of exercise. The number of patients developing angina during the exercise test did not vary significantly in the three treatment periods-nine with practolol, nine with propranolol, and eight with placebo.

The electrocardiographic changes during the exercise tests are shown in Table III. The amount of S-T depression in the

Table III.-S-T Depression during Exercise Tests in 15 Patients

\begin{tabular}{|c|c|c|c|c|c|}
\hline & & \multicolumn{2}{|c|}{ Radiocardiogram } & \multicolumn{2}{|c|}{ Lead V5 } \\
\hline & & $\underset{(\mathrm{mm} .)}{\text { Amount }}$ & $\begin{array}{l}\text { Duration } \\
\text { (seconds) }\end{array}$ & $\underset{(\mathrm{mm} .)}{\text { Amount }}$ & $\begin{array}{l}\text { Duration } \\
\text { (seconds) }\end{array}$ \\
\hline $\begin{array}{l}\text { Placebo: } \\
\text { Mean } \\
\text { S.E. }\end{array}$ & $\because$ & $\begin{array}{l}1 \cdot 0 \\
0 \cdot 16\end{array}$ & $\begin{array}{r}233 \\
22\end{array}$ & $\begin{array}{l}0 \cdot 40 \\
0 \cdot 07\end{array}$ & $\begin{array}{r}284 \\
19\end{array}$ \\
\hline $\begin{array}{lr}\text { Practolol: } \\
\text { Mean } \\
\text { S.E. } \\
\text { Mean change } \\
\text { S.E. } \\
\begin{array}{ll}\text { P. } & \ldots \\
\text { P } & \ldots\end{array}\end{array}$ & $\begin{array}{l}. \\
\cdots \\
\cdots \\
.\end{array}$ & $\begin{array}{c}0.67 \\
0.12 \\
-0.33^{*} \\
0.13 \\
<0.01\end{array}$ & $\begin{array}{r}265 \\
37 \\
+15 \\
29\end{array}$ & $\begin{array}{r}0.47 \\
0.11 \\
-0.07 \\
0.12\end{array}$ & $\begin{array}{r}277 \\
8 \\
-30 \\
26\end{array}$ \\
\hline $\begin{array}{l}\text { Propranolol: } \\
\text { Mean } \\
\text { S.E. } \\
\text { Mean change } \\
\text { S.E. } \\
\begin{array}{ll}\text { P. } & \ldots \\
& \ldots\end{array}\end{array}$ & $\begin{array}{l}. \\
\cdots \\
\cdots \\
\therefore\end{array}$ & $\begin{array}{r}0.67 \\
0.16 \\
-0.33 \\
0.21 \\
>0.05\end{array}$ & $\begin{array}{r}283 \\
7 \\
+24 \\
25\end{array}$ & $\begin{array}{c}0.40 \\
0.11 \\
0 \\
0.13\end{array}$ & $\begin{array}{c}267 \\
15 \\
-8 \cdot 6 \\
23\end{array}$ \\
\hline
\end{tabular}

* Significant change $(P<0.05)$. 
radiocardiogram during exercise was significantly reduced by practolol compared with the placebo, but propranolol had no significant effect. Neither practolol nor propranolol significantly influenced the degree of $S-T$ depression after exercise in V5. The duration of $\mathrm{S}-\mathrm{T}$ depression in either the radiocardiogram or in lead V5 was not significantly affected by either practolol or propranolol; the apparent discrepancies between the mean change figures and the figures obtained by subtracting the group means from each other is due to the differing numbers of patients contributing to the mean change result and the mean result. Whereas the mean for each group was calculated by averaging all patients showing $S-T$ depression in that group, the mean change between two different groups-for example, placebo and practolol-was calculated by averaging the individual differences only in patients showing $S-T$ depression in both groups, so that patients exhibiting S-T depression in one only treatment group were excluded from the estimation of mean change results.

Both practolol and propranolol produced a significant reduction in heart rate before and immediately after exercise, and, in addition, practolol, but not propranolol, significantly reduced the mean change between the pre-exercise and post-exercise heart rate (Table IV). Both drugs significantly

Table IV.--Heart Rate during Exercise Tests in 15 Patients

\begin{tabular}{|c|c|c|c|c|}
\hline & & Placebo & Practolol & Propranolol \\
\hline $\begin{array}{c}\text { Before exercise: } \\
\text { Mean } \\
\text { S.E... } \\
\text { Mean change } \\
\text { S.E... } \\
\begin{array}{ll}\text { P } & \ldots\end{array}\end{array}$ & $\begin{array}{l}. \\
\because \\
\therefore\end{array}$ & $\begin{array}{r}82 \cdot 3 \\
5 \cdot 1\end{array}$ & $\begin{array}{c}70.6 \\
2.3 \\
-11.7^{*} \\
4.3 \\
<0.01\end{array}$ & $\begin{array}{c}65.9 \\
4.6 \\
-16.4^{*} \\
7.2 \\
<0.02\end{array}$ \\
\hline 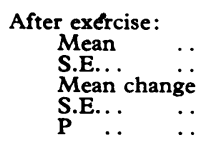 & $\begin{array}{l}\ldots \\
\cdots \\
\cdots\end{array}$ & $\begin{array}{r}116.9 \\
6.0\end{array}$ & $\begin{array}{c}95.5 \\
3.2 \\
-21.4^{*} \\
5.0 \\
<0.001\end{array}$ & $\begin{array}{c}95.9 \\
7.5 \\
-21.0^{*} \\
8.7 \\
<0.01\end{array}$ \\
\hline 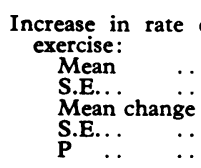 & $\begin{array}{l}\text { to } \\
\ldots \\
\vdots \\
\therefore \\
\cdots\end{array}$ & $\begin{array}{r}33.9 \\
3.5\end{array}$ & $\begin{array}{c}24.9 \\
2.5 \\
9.0 * \\
3.1 \\
<0.005\end{array}$ & $\begin{array}{c}30.0 \\
4.9 \\
3.9 \\
3.9 \\
>0.15\end{array}$ \\
\hline
\end{tabular}

* Significant change $(P<0.05)$.

reduced the systolic pressure, whether lying or standing (Table V). Practolol also produced a significant fall in the standing diastolic pressure while propranolol significantly

TABle V.-Blood Pressure Changes in 15 Patients after Administration of Placebo, Practolol, and Propranolol

\begin{tabular}{|c|c|c|c|c|c|c|}
\hline & & & \multicolumn{2}{|c|}{$\begin{array}{c}\text { Systolic Pressure } \\
\text { (mm. Hg) }\end{array}$} & \multicolumn{2}{|c|}{$\begin{array}{l}\text { Diastolic Pressure } \\
(\mathbf{m m} . \mathbf{H g})\end{array}$} \\
\hline & & & Lying & Standing & Lying & Standing \\
\hline $\begin{array}{c}\text { Placebo: } \\
\text { Mean } \\
\text { S.E. }\end{array}$ & 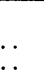 & $\begin{array}{l}\cdots \\
\cdots\end{array}$ & $\begin{array}{r}145 \cdot 7 \\
6 \cdot 8\end{array}$ & $\begin{array}{r}141 \cdot 6 \\
5 \cdot 3\end{array}$ & $\begin{array}{r}90 \cdot 1 \\
3 \cdot 5\end{array}$ & $\begin{array}{r}91 \cdot 2 \\
3 \cdot 3\end{array}$ \\
\hline $\begin{array}{l}\text { Practolol: } \\
\text { Mean } \\
\text { S.E. } \\
\text { Mean chang } \\
\text { S.E. } \\
\text { P .. . }\end{array}$ & $\begin{array}{l}. \\
\text { ge } \\
\cdots \\
\cdots\end{array}$ & $\begin{array}{l}\cdots \\
\cdots \\
\cdots \\
\cdots\end{array}$ & $\begin{array}{c}134.3 \\
6.9 \\
-11.4^{*} \\
3.9 \\
<0.005\end{array}$ & $\begin{array}{c}132 \cdot 7 \\
5.5 \\
-8.9 * \\
4 \cdot 1 \\
<0.02\end{array}$ & $\begin{array}{r}86.4 \\
3.2 \\
-3.7 \\
3.1 \\
>0.1\end{array}$ & $\begin{array}{c}86.9 \\
3.1 \\
-4.3^{*} \\
2.4 \\
<0.05\end{array}$ \\
\hline $\begin{array}{l}\text { Propranolol: } \\
\text { Mean } \\
\text { S.E. } \\
\text { Mean chang } \\
\text { S.E. } \\
\text { P .. }\end{array}$ & $\begin{array}{l}\cdots \\
\ddot{g e} \\
\cdots\end{array}$ & $\begin{array}{l}\ldots \\
\cdots \\
\cdots \\
\cdots\end{array}$ & $\begin{array}{c}136.0 \\
5.0 \\
-9.7 * \\
5.0 \\
<0.05\end{array}$ & $\begin{array}{c}133.1 \\
4.8 \\
-8.5^{*} \\
2.9 \\
<0.02\end{array}$ & $\begin{array}{c}82 \cdot 1 \\
2 \cdot 2 \\
-8 \cdot 0^{*} \\
3 \cdot 4 \\
<0.01\end{array}$ & $\begin{array}{c}84.6 \\
2.0 \\
-6.6^{*} \\
2.3 \\
<0.02\end{array}$ \\
\hline
\end{tabular}

* Significant change $(P<0.05)$

reduced both lying and standing diastolic pressure. The effects of the drugs on small airway resistance are shown in Table VI. Though neither drug significantly altered the
TABLE VI.-Effect of Practolol, Propranolol, and Placebo on F.E.V. ${ }_{1}$

\begin{tabular}{|c|c|c|c|c|}
\hline & & Placebo & Practolol & Propranolol \\
\hline $\begin{array}{lr}\text { F.E.V.1 (litres): } \\
\text { Mean } & \ldots \\
\text { S.E... } & \ldots \\
\text { Mean change } \\
\text { S.E... } \\
\begin{array}{ll}\text { P . } & \ldots\end{array}\end{array}$ & $\begin{array}{l}\cdots \\
\cdots \\
\cdots \\
\cdots\end{array}$ & $\begin{array}{l}2.63 \\
0.20\end{array}$ & $\begin{aligned} 2.62 \\
0.19 \\
-0.01 \\
0.05 \\
>0.4\end{aligned}$ & $\begin{array}{r}2.46 \\
0.18 \\
0.17 \\
0.11 \\
>0.05\end{array}$ \\
\hline $\begin{array}{lr}\text { F.M.F. (litres/min. } \\
\text { Mean } \\
\text { S.E... } \\
\text { Mean change } \\
\text { S.E... } \\
\text { P } . . & \ldots\end{array}$ & $\begin{array}{l}\ldots \\
\cdots \\
\cdots\end{array}$ & $\begin{array}{r}145.7 \\
18.8\end{array}$ & $\begin{array}{r}145.5 \\
16.7 \\
-0.2 \\
7.0 \\
>0.3\end{array}$ & $\begin{array}{c}125.5 \\
15 \cdot 6 \\
-20 \cdot 2 * \\
7.1 \\
<0.005\end{array}$ \\
\hline
\end{tabular}

*Significant change $(\mathrm{P}<0.05)$.

F.E.V.1 compared with the placebo, propranolol led to a significant reduction of the F.M.F., a more sensitive index of small airway obstruction than the F.E.V.1. Comparison of practolol and propranolol with each other showed a significantly lower F.E.V.1 $(P<0.05)$ and F.M.F. $(P<0.002)$ with propranolol.

\section{Dosage and Side-effects}

The dose of practolol used in the trial ranged from 200 to $600 \mathrm{mg}$. b.d., the dose for individual patients being determined in the "open" part of the trial at the beginning of the study. The side-effects of practolol included dizziness in five patients (though none showed an unduly low blood pressure), depression in three, and nausea and vomiting in three. Gastrointestinal upsets also occurred in two patients treated with propranolol, and another patient had dizziness on propranolol. While having placebo treatment, four patients also developed side-effects, including dizziness, blurred vision, and diarrhoea. Practolol had no effect on the routine screening tests, such as haemoglobin, white cell count, platelet count, blood urea, and liver function tests.

\section{Discussion}

The value of sympathetic beta-receptor blocking agents in the treatment of angina has already been well established (Gillam and Prichard, 1965; Birkett and Chamberlain, 1966; Grant et al., 1966; Sandler et al., 1968), and the present study confirms the efficacy of the new beta-blocking drug, practolol, in treating this condition. Though practolol did not significantly affect the subjective criteria, including the number of attacks recorded by the patient or the glyceryl trinitrate consumption, it did significantly improve the more objective indices of myocardial ischaemia, such as the amount of exercise possible and, more important, the degree of ischaemic $\mathrm{S}-\mathrm{T}$ depression in the radiocardiogram during exercise; in this respect it was superior to propranolol in a dose of $80 \mathrm{mg}$. q.d.s., which did not significantly alter the amount of S-T depression induced by exercise. The betablocking action of both drugs was confirmed by the significant reduction in heart rate produced by them, both in the resting patient and following exercise. The favourable effect of practolol on coronary insufficiency is unlikely to be due solely to its negative chronotropic action and may be associated primarily with reduction of myocardial contractility (Areskog and Adolfsson, 1969).

Two of the main disadvantages encountered with propranolol treatment have been the deleterious effect on myocardial function due to its negative inotropic action (Chamberlain, 1966; Shanks, 1966; Stephen, 1966) and bronchospasm due to beta-receptor blockade in the bronchial tree (McNeill, 1964). Practolol differs from propranolol in animal experiments by having less than half the inhibitory effects of propranolol on isoprenaline-induced tachycardia and on mobilization of free 
fatty acid (Barrett et al., 1968), and, unlike propranolol, practolol was also found to have some intrinsic sympathomimetic action (Sowton et al., 1968) and no local anaesthetic (quinidine-like) action (Dunlop and Shanks, 1968). In view of these considerations practolol might be expected to exert a less adverse effect on myocardial function than propranolol. A negative inotropic effect, however, has been found by Gibson and Sowton (1968) and Sowton et al. (1968) when using a large intravenous dose of $25 \mathrm{mg}$., though it was not evident with a 5-mg. dose of practolol. Possibly the significant fall in systolic pressure (lying and standing) produced by practolol in the present study may represent a negative inotropic effect, though the accompanying fall in heart rate induced by practolol may also be an important factor in this respect. There is as yet no convincing evidence that practolol can be given with impunity to patients with cardiac failure, and it would be advisable to continue to administer the drug cautiously when myocardial dysfunction is present.

The bronchospastic effect of propranolol has been confirmed in the present study, while practolol was found to exert no significant effect on small airway resistance in our 15 patients. This confirms other studies showing that doses of practolol which were capable of blocking cardiac betareceptors had no significant effects on the beta-receptors of vascular and bronchial smooth muscle (Barrett et al., 1968; Dunlop and Shanks, 1968; McDonald and McNeill, 1968). This represents an important advantage of practolol over propranolol, since it means that practolol can be used freely in a large section of the population with combined angina and asthmatic bronchitis, where propranolol may adversely affect the respiratory function.

The blood pressure response to practolol in the present study is worthy of comment. It has been claimed that practolol has no significant effect on vascular smooth muscle, but there was a significant fall in the standing diastolic pressure following treatment with the drug. This suggests that practolol in the dose range used in the present study does in fact have some effect on the peripheral arterioles, and this may well have been an important factor in the patient who developed severe hypotension while having practolol and had to be withdrawn from the trial. Hence a close watch should be kept on the blood pressure whenever an anginal patient is treated with practolol, just as similar close observation is required with propranolol treatment.

We are grateful to Mr. B. Bamford and Miss V. Clarke for technical assistance with the electrocardiography. We should also like to thank Dr. W. H. M. Jewell, of I.C.I. Ltd., for supplies of drugs used in the trial; and Mr. A. M. Tucker for help with the statistical analysis.

\section{REFERENCES}

Areskog, N. H., and Adolfsson, L. (1969). British Medical fournal, 2, 601.

Barrett, A. M., Crowther, A. F., Dunlop, D., Shanks, R. G.; and Smith, L. H. (1968). Naunyn-Schmiedeberg's Archiv für Pharmakologie und experimentelle Pathologie, 259, 152.

Bellet, S., Eliakim, M., Deliyiannis, S., and La Van, D. (1962). Circu-

Birkett, D. A., and Chamberlain, D. A. (1966). British Medical fournal, 2, 500

Black. J. W., Crowther, A. F., Shanks, R. G., Smith, L. H., and Dornhorst, A. C. (1964). Lancet, 1, 1080

Chamberlain, D. A. (1966). Cardiologia, 49, Suppl. No. 2, p. 27.

Dornhorst, A. C., and Robinson, B. F. (1962). Lancet, 2, 314.

Dunlop, D., and Shanks, R. G. (1968). British Fournal of Pharmacology and Chemotherapy, 32, 201.

Fitzgerald, J. D., and Scales, B. (1968). Internationale Zeitschrift für Klinische Pharmakologie, Therapie und Toxikologie, 1, 467.

Gibson, D., and Sowton, E. (1968). British Medical fournal, 1, 213.

2, 337 Grant, R. H. E., et al. (1966). American fournal of Cardiology, 18,

Greiner, T., et al. (1950). American fournal of Medicine, 9, 143.

Hamer, J., Grandjean, T. Melendez, L., and Sowton, G. E. (1964). British Medical fournal, 2, 720.

Hamer, J., and Sowton, E. (1966). American fournal of Cardiology, 18, 354.

Keelan, P. (1965). British Medical fournal, 1, 897.

Leuallen, E. C., and Fowler, W. S. (1955). American Review of Tuberculosis and Pulmonary Diseases, $72,783$.

Lloyd-Thomas, H. G. (1961). British Heart fournal, 23, 561.

Macdonald. A. G., and McNeill, R. S. (1968). British fournal of Anaesthesia, 40, 508.

McNeill, R. S. (1964). Lancet, 2, 1101.

Master, A. M., and Rosenfeld, I. (1961). Fournal of the American Medical Association, 178, 283.

Sandler, G. (1961). British Medical fournal, 1, 792.

Sandler, G. (1967). British Heart fournal, 29, 719.

Sandler, G., Clayton, G. A., and Thornicroft, S. G. (1968). British Medical fournal, 3, 224 .

Shanks, R. G. (1966). American fournal of Cardiology, 18, 308.

Sowton, E.. Balcon, R., Cross, D., and Frick, H. (1968). British Medical Fournal, 1, 215.

Stephen, S. A. (1966). American fournal of Cardiology, 18, 463.

Wilcoxon, F. (1945). Biometrics, 1, 80.
Wolfson, S., et al. (1966). American fournal of Cardiology, 18, 345.

\title{
Practolol in Treatment of Angina Pectoris. A Double-blind Trial
}

\author{
C. F. GEORGE, ${ }^{*}$ M.B., M.R.C.P. ; R. E. NAGLE, $†$ M.B., M.R.C.P. ; B. L. PENTECOST, † M.D., M.R.c.P.
}

British Medical fournal, 1970, 2, 402-404

\begin{abstract}
Cummary: Twenty-four patients with angina pectoris $\checkmark$ entered a double-blind trial of the cardioselective beta-adrenergic blocking agent practolol. Seventeen experienced less angina and consumed fewer glyceryl trinitrate tablets when on the active preparation. There was also a decrease in the mean number of attacks suffered by patients while on practolol and a reduction in the number of glyceryl trinitrate tablets taken. These results are of statistical significance at, at least, the $5 \%$ level.
\end{abstract}

\section{Introduction}

Pharmacological blockade of the sympathetic nervous impulses to the heart is now an accepted method of treatment for angina (British Medical fournal, 1969). In a number of clinical trials propranolol has been shown to reduce the fre-

* Medical Registrar, the General Hospital, Birmingham 4.

t Consultant Physician, the United Birmingham Hospitals. quency of angina attacks and the consumption of glyceryl trinitrate (Gillam and Prichard, 1965; Keelan, 1965; Grant et al., 1966; Gianelly et al., 1967). All beta-adrenergic agents, however, may increase airways resistance, especially when there is a tendency to asthma (MacDonald et al., 1967). As angina and obstructive airways diseases. not uncommonly exist in the same patient, the respiratory problems may be aggravated and prevent the administration of the optimum dose of beta-blocking drug. Practolol is cardioselective and causes less increase in airways resistance than propranolol (MacDonald and McNeill, 1968). A preparation of this kind could offer certain practical advantages over propranolol. Therefore a controlled trial was conducted in order to assess the efficacy of practolol in angina pectoris.

\section{Patients and Methods}

The first aim was to establish the dose of practolol at which symptomatic relief was obtained, but an arbitrary upper limit 